\title{
Depicting the Ethereal, Part I: Visual Art and Psi ${ }^{12}$
}

\author{
Etzel Cardeña
}

Lund University

\begin{abstract}
The turn from figurative art to the depiction of internal experiences opened the door for artists to represent anomalous experiences and ostensible psi phenomena. Various studies have described how Abstract art was influenced by Occultism, but there were other important influences. They include scientific theories of the ether and hypergeometric dimensions, the development of technological advances showing the reality of unseen electromagnetic waves and wireless communication at a distance, Spiritualism, and the inception of psychical research. This paper focuses on how psi phenomena, research, and theory, often in conjunction with the other influences, have been an important topic and source of inspiration in various modern and contemporary movements including Surrealism and Abstract and Conceptual art.
\end{abstract}

Keywords: psi; parapsychology; psychical research; art; Abstract Art; Surrealism; Conceptual Art.

Paul Klee wrote that "Art does not reproduce the visible but makes visible" (1920), exemplified in his own paintings and drawings of ostensible mediumistic materializations, levitation, and automatic writing (Okuda, 2011). Thus, his statement can be interpreted as a dictum that art should depict not only occultist symbols (e.g., Rosenthal, 1982) but also ostensible parapsychological/psychic (psi) phenomena. The characteristic disdain for all things psi expressed by some academics and the laughably biased entries in Wikipedia has its counterpoint in their importance and acceptance by many visual artists, particularly since the late 1800s. The influence of occultist beliefs in modern art, particularly Abstract, has been recognized for decades (e.g., Henderson, 1987; Tuchman, 1986), but more recent scholarhip has shown that such beliefs (not necessarily antagonistic to belief in scientific theories and discoveries) and ostensible psi experiences have also influenced other modern and contemporary art movements. In major and minor museums throughout the world, there has been a growing number of unapologetic and very popular exhibits on art, Occultism, and psi phenomena and research. Museum blockbusters during the last twenty years, some of them with the collaboration of dozens of collections throughout the world include:

1 The author is very thankful for the previous collaboration with Ana Iribas and Sophie Reijman, which ignited my interest. My deep gratitude also to Professor Linda Dalrymple Henderson for her foundational scholarship and kind and thorough review. Thank you as well for the helpful critiques and suggestions of Carlos Alvarado, Renaud Evrard, Lauren Reid, and Sophie Reijman. Address correspondence to: Etzel Cardeña, Ph. D., Thorsen Professor of Psychology, Department of Psychology, Lund University, 22100, Sweden, etzel.cardena@psy.lu.se 2 Chris Roe, Ph. D., was Action Editor for this paper. 
- "The Disembodied Spirit," at the Austin Museum of Art (Ferris et al., 2003).

- "The Perfect Medium: Photography and the Occult," at the Metropolitan Museum of Art (Chéroux, et al., 2004).

- “The Message: Kunst und Okkultismus,"at the Kunstmuseum Bochum, in Köln (Dichter et al., 2007; for a review see Cardeña, 2012).

- "Susan Hiller," a major retrospective of her work at the Tate Britain, 2011 (see Iribas, 2020).

- "L'Europe des Esprits ou la fascination de l'occulte. 1750-1950" at the Museum of Modern and Contemporary Art in Strasbourg (Pijaudier-Cabot \& Fauchereau, 2011).

- "Schwarze Romantik: Von Goya bis Max Ernst," at the Städel Museum in Frankfurt am Main, 2013, and the Musee d'Orsay (Krämer, 2012).

- "Cosa Mentale," at the Pompidou-Metz, 2016, probably the most focused exhibit on psi and art (Rousseau, 2015).

Furthermore, the recently rediscovered mediumistic work of the extraordinary Swedish painter Hilma af Klint (Fant, 1989; Henderson, 2019) has toured major venues throughout the world. Her work and that of other mediumistic artists preceding and following her (Althaus et al., 2018) are rewriting the history of Western art. There have also been smaller relevant exhibits in France (Evrard \& Méheust, 2012), Japan (Safarova et al., 2012), Spain, 2019 (https://www.esbaluard.org/exposicion/ alma-mediums-visionarias/), Sweden (Lundskonsthall, 2013), and the USA, 2005 (https://cadvc.umbc. edu/blur-of-the-otherworldly-contemporary-art-technology-and-the-paranormal/). A common, and unfortunate, characteristic of many of these exhibits, though, is that they have rarely differentiated between Occultism/esoterism and psi.

To help carify this issue, I will distinguish the domain of psi research from the only partly overlapping area of Occultism, with which it has been conflated in art history. Parapsychology/psychical research are sometimes used interchangeably, but a finer distinction is that psychical research was the initial term and sometimes is used to differentiate the scientific naturalistic study of psi phenomena, for instance in Spiritualist séances, from parapsychology, or the experimental study in a laboratory of such phenomena. What both types of investigation share in common is a commitment to the scientific method. Particularly at its inception, psi research adopted adopted the scientific method as described by Riskin (2020. P. 48) more generally: "an integral approach to understanding the natural world." From this perspective, ostensible psi phenomena were evaluated where and as they occurred naturally, be it in a mediumistic séance or spontaneous experiences of, for instance, a vision of someone who was unexpectedly dying far away.

Psychical research was institutionalized in 1882 through the foundation by eminent scientists and philosophers of the (British) Society for Psychical Research, whose goal was "to examine without prejudice or prepossession and in a scientific spirit those faculties of [hu]man, real or supposed, which appear to be inexplicable on any generally recognised hypothesis" (https://www.spr.ac.uk/publicationsrecordings/journal-society-psychical-research). Other aspects of science were present then as today and in- 
clude the testing of alternative explanations or hypotheses, thorough and open communication of the procedure employed and the results, and an ongoing dialogue with scientists from different persuasions.

And what are psi phenomena? They comprise ostensible accurate information or influence from spatially or temporally distant events not mediated through the senses or reason (also known as anomalous cognition or ESP, including so-called telepathy, clairvoyance, precognition, and retrocognition). An example of ostensible ESP would be to think of a person from the past one had not thought of in years the same day that that person sends one an unexpected email. Another area of study is the study of ostensible direct mental effect on microscopic or large objects (i.e., anomalous perturbation or force, psychokinesis, PK, or telekinesis), as in a clock suddenly and without reason ceasing to work at the time that his/her owner dies. The final main area of study includes research on the possibility of human survival, as when a person (e.g., a medium) reveals precise information about a deceased individual that is nor probable or discernible from the behavior of the client (for a review of the concept and research on all these areas see Cardeña et al., 2015).

Beliefs in the reality of psi phenomena in general or as the result of the development of a higher consciousness level are not infrequent in Occult schools such as Theosophy and Anthroposophy, but there also fundamental distinctions between them and psi research. An essential one is that parapsychology does not take psi phenomena as a given but evaluates them scientifically. Other distinctions are that schools of Occultism may follow reputed secret traditions and texts, use magical incantations and formulas, adopt specific symbols as in the Tarot cards, or follow esoteric rituals (see, Lingan, 2014, for a description of various tenets of Occultism; see also Cardeña, 2019a). Thus tarot, kabbalah, magic, or religious or spiritual beliefs and practices should not be confused with psi research.

The warm embrace by art of the "unseen" (including ostensible psi phenomena) was multidetermined. One source, particularly since the end of the $19^{\text {th }}$ century (although with predecessors such as Goya, see Hoffman, 2010; Krämer, 2012; Sueur-Hermel, 2016) was the goal to express subjective experiences through painting and sculpture, sometimes questioning any strong demarcation between the inner and the outer, the objective and the subjective. Furthermore, some artists read about recent scientific discoveries and ideas, some of which supported their own ideas and ostensible psi experiences. An example is the Abstract painter and writer Kandinsky, who kept himself well informed of psychical research. In an edition of his very influential book The Spiritual in Art (1911/1979), he evidenced in footnote 7 familiarity with the work of at least 5 psychical researchers (Crookes, Flammarion, Lombroso, Richet, and Zöllner; see also Méheust, 1999, who describes the influence of psychical research in the work of Kandinsky). Noakes (2019) and other contemporary historians of science have pointed out that very important investigators at the end of the $19^{\text {th }}$ century integrated modern scientific findings and theories with such research, challenging the notion that science is antithetical to psi research (and some ideas also held by occultists). ${ }^{3}$

Another reason for the interest of artists in depicting subjective experiences was that some of them had unusual experiences that were not being recognized in polite company then (or, to an ex-

3 For a list of Nobel prizewinners and other eminent scientists and creators with a serious interest in psi see Cardeña, 2015; for a list of 100 academics, some of first rank universities, calling for an open inquiry of psi phenomena, see Cardeña, 2014. 
tent, now, see Cardeña et al., 2017). This is expectable since artists tend to experience "thinner" mental boundaries between them and the "outside" world than average (Hartmann et al., 2001), blurring distinctions between "inner" and "outer" experiences, and have uncommon perceptual experiences and beliefs (Holt, 2019). That the latter are not only "subjective" is suggested by controlled psi experiments, in which artists tend to perform significantly better than chance (e.g., having a 50\% hit rate when $25 \%$ would be expected by chance, Schlitz \& Honorton, 1992) and better than individuals who are not artists or do not follow mental disciplines such as meditation (Baptista et al., 2015). Consistent with this research, a high proportion of individuals who have shown consistent good performance in controlled psi studies have been artists, for instance the medium Mrs. Leonard and the remote viewer Ingo Swann (see Cardeña et al., 2012). Some current psi researcher have adopted artistic activity as a criterion to select individuals more likely to perform well in a psi experiment (e.g., Watt et al., 2020).

After publishing, with two colleagues, a paper reviewing some of the experimental and anecdotal literature tying psi and the visual arts and literature (Cardeña et al., 2012), I continued to study the topic and found that it deserved a lengthier treatment. This paper, the first in a series of two, focuses on art and psi. The second will turn its gaze to alterations of consciousness and psi. The distinction is partly arbitrary because there are some manifestations, such as The Dream Seminar by Susan Hiller (1973; see Iribas, 2020), that overlap art, other states of consciousness, and ostensible psi. And, depending on how one interprets the source of channeled or mediumistic art, it is the manifestation of idiosyncratic personal and cultural processes, telepathic communication with living, spiritual or deceased entities, or a mixture of some or all of these processes. For clarity's sake and since I do not think that it will be contested that mediumistic art involves an alteration of the ordinary state of consciousness, I will mostly discuss it in the second of these papers.

\section{The Dissolution of Matter and the Subjective/Objective Distinction}

Making a blunt discrimination in the history of Western Art, at the end of the $19^{\text {th }}$ century there was a swerve from trying to depict the "natural" world (e.g., objects, landscape, or people) from consensually perceived reality (i. e., representational or figurative art) to increasingly focus on the "inner" or subjective experience of the artist. Initial movements such as Romanticism and Symbolism sought to portray inner moods and other states, although still leaning on naturalistic images and conventions (e.g., Krämer, 2012). Later, non-representational art more clearly divorced itself from such imagery. As Rousseau (2015, p. 78) writes, quoting the Symbolist writer Kahn, some of the art of that time attempted to "objectify the subjective," to depict not only what is seen, but what is being felt and intuited.

This change had many variations, including the emotionally intense chromatic expressionism of Kokoschka's oils, the transformation of matter into energy and vice versa in works by the Futurist Buccioni (Henderson, 2002; Rousseau, 2015), and the ominous representations of a purported vibratory protoplasm in the work of Munch and Strindberg (the latter an important painter besides a trailblazing writer) (Brain, 2010). The pull away from a sharp distinction between the subjective and the objective had diverse causes. One of them was the idea that "subjective" experiences have universal configurations, as proposed by the Theosophists Annie Besant and Charles W. Leadbeater in their influential book Thought-Forms (1901). They stated that they had clairvoyantly found out that thoughts, emotions, 
and aesthetic experiences had specific forms, colors, and dynamics. Their idea would impact the ideas and works of various Abstract Art painters including Kandinsky, Mondrian, and Kupka (Anderson, 2011; Ringbom, 1986; Rousseau, 2015). Theosophy and later Anthroposophy were also very important influences in the work of an Abstract painter who has been arguably advanced as a pioneer of Modernist Abstraction, Hilma af Klint (see Tallman, 2019). And the Abstract mediumistic art of of Georgiana Houghton, full of translucent, colorful swirls and unusual geometrisma preceded that of af Klint for decades (Althaus et al., 2018). Houghton, by the way, was also the author of a book on purported spirit photographs (Houghton, 1882).

The general idea by Besant and Leadbeater that certain emotions, thoughts, or other subjective experiences have a universal representation in form and color is not farfetched, if we restrict it to how humans establish intermodal matching. Even though synesthetic matching of the senses is idiosyncratic rather than universal, there are some regularities. For instance, psychologist Köhler (1929) tested what is now known as the "bouba/kiki" effect, in which, from infancy, some qualities are cross-culturally associated with certain shapes. This is an instance of more general inborn tendencies to match different sensory stimulation, such as high pitch with brightness (Marks, 2000).

Unification of the subjective and objective was also present among some Zürich Dadaists, as in this quotation by Hans Arp, who advocated for: "the Absolute, for the unpartedness of nature and spirit, object and subject" (in Wynands, 2001, p. 82). The Dadaists' serious regard of chance events as triggers for art was also indicative of a presumption of a general hidden order in the universe for both "objective" and "subjective" events, anticipating surrealism's own take on the issue. In a less synesthetic way than that offered by the Abstract artists, the Surrealists sought to reveal directly the unconscious psyche of the artist by such techniques as depicting automatic messages, images from dreams, and so on. Correspondences between mental and material "stuff" would follow what Charles Duits, a writer friendly with the Surrealists, wrote about psi phenomena, namely that they are incompatible with a dualist mind/ matter conception of the universe but are "possible and plausible if a porous and diaphanous partition separates the "objective' from the 'subjective'" (Duits, 1974, in Duplessis, 2002; my translation).

Photography, already from the end of the 19th century was employed not only to provide dubious evidence of the Spiritual world in manipulated photographies, but also, conversely, to assist psychical researchers documenting mediumistic levitations and ectoplasm. Photography would also be employed by Baraduc, Darget, and others to offer what they considered concrete manifestations of such matters as the soul leaving the body, or subjective experiences such as nightmares, thoughts, or emotions, initiating what would later be known as thoughtography (Oursler, 2019; Rousseau, 2015).

The concretization of the subjective was also advanced by scientific inventions producing graphic displays of brain/mental events. The first important brain imaging technique was the electroencephalogram (EEG), initially devised by Berger to measure psi phenomena, after his sister sensed that he was in danger at the time he had a riding accident in a distant place (Berger, 1940; for other proposals to visualize thoughts see Rousseau, 2015). Enns (2013) discusses the interconnections between photography, brain waves, psi phenomena, and Abstract art at their inception.

The reality of the unseen was also manifested through technological inventions showing that only a very small segment of the electromagnetic spectrum is perceivable, whereas other bands were re- 
sponsible for radio wireless transmission or for deadly radiations. And the work of some psi researchers, for instance the physicist and psi researcher Crookes, was fundamental to the development of wireless communication (Noakes, 2019). Thus, artists could read in texts in physics, psychical research, some esoteric traditions, and mesmerism/animal magnetism that they might be affected by unseen influences and might be able to affect others at a distance (Rousseau, 2015). From some of these texts, they could also deduce that their thoughts and emotions could affect others at a distance. This was given a precise rendition in the 1924 embroidery by the Brut artist (she was confined in an insane asylum) Jeanne Natalie Wintsch's Je suis radio (I am radio) (Fig, 1, see also Althaus et al., p. 16). Similarly, the metaphorical marriage of new technology and psi is present in the title of the book Mental Radio (Sinclair, 1930, with a preface by Einstein) on the telepathic experiments, using often drawings as stimuli, of the writer Upton Sinclair and his wife, Mary Craig Kimbrough. Attempts to use technology to "mind read" or, more modestly, achieve "noun identification" through the evaluation of brain activity, continue to our days (e.g., Mitchell et al., 2008).

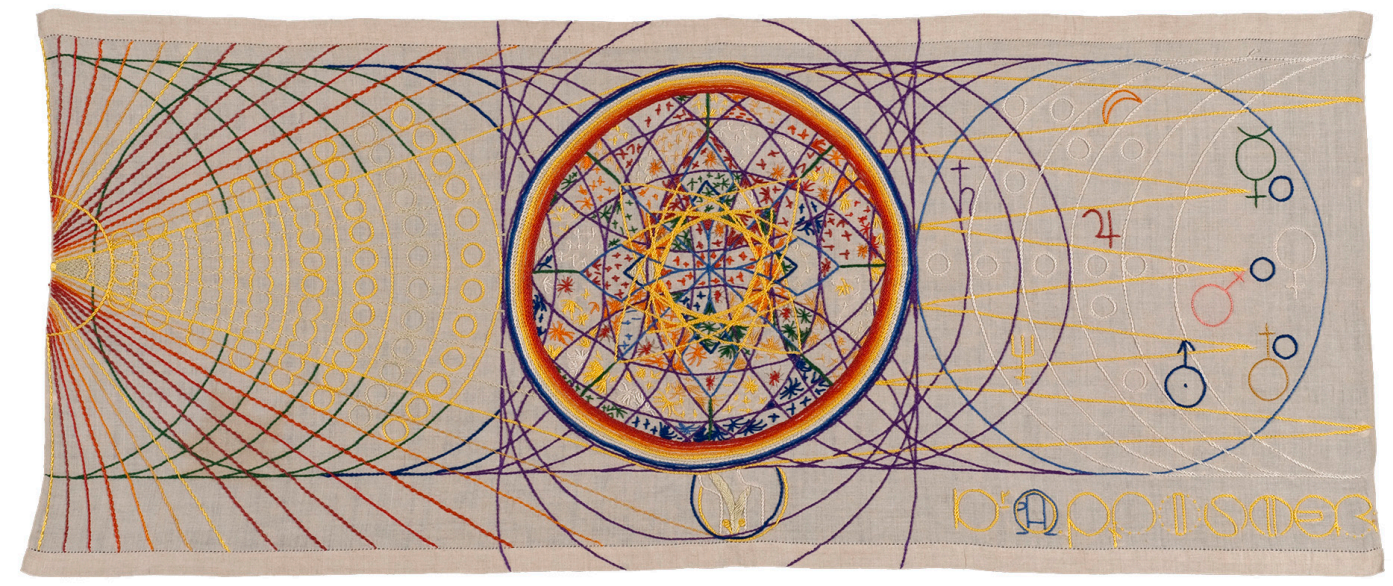

Fig. 1. Jeanne Natalie Wintsch's embroidery Je suis radio. (C) Canton Zurich.

The interpenetration of scientific discoveries and interest in psi phenomena and their potential implications was present in the writings and work of foundational artists at the turn of the 20th century (Bauduin, 2012; Henderson, 2014). One reason is that psi phenomena seemed to challenge a sharp distinction between mind and matter. Anomalous cognition suggested that mental events can be influenced by information about "objective" events that are distant in space (telepathy, clairvoyance) or time (precognition); whereas psychokinesis suggested that intentions can have a direct effect on matter (for a recent study on this proposal see Radin, Michel, \& Delorme, 2016). One of the founders of Futurism, Marinetti, conceived of a human machine to create the ectoplasmic manifestations of séances and externalize human Will (in Brain, 2013, p. 136). And scientists (and some artists and occultists) proposed that the all-pervading substance of ether and an unseen spatial dimension explained how this all happened...

\section{Things Are not as They Seem: The Ethereal Reality}

Parallel to the concretization of the subjective was the dissolution of matter. Idealist philosophies have always proposed that the ultimate stuff of the universe is subjective, but at the turn of the 19th cen- 
tury some scientific findings and theories reinforced the idea that the substrate of reality was not matter in the sense considered until then. As the influential astronomist Camille Flammarion wrote in 1907 during a discussion of his psychical research, matter is not "what it appears to be to our vulgar senses... [but] a manifestation of the movement of invisible and imponderable elements" (p. 23). Similarly, some Romantic and Symbolist artists at the end of the 19th and beginning of the 20th centuries posited a hidden order of reality (Henderson, 1986; Krämer, 2012), an idea that also influenced other artistic disciplines such as dramatic texts and performances by Theosophist and other groups (Lingan, 2014).

Flammarion was following the implications of recent discoveries and inventions that showed the limitations of the senses and the existence of vast unseen influences, among them: electromagnetic waves (by Hertz), radio transmission (by Marconi), radiotelegraphy (by various, including Thomas Alva Edison), X-rays (by Röntgen), and radiation (Becquerel, Marie and Pierre Curie). Incidentally, of these seven figures, mentioned in a paper by Henderson (2014), only Röntgen and Becquerel do not seem to have had any known interest in psi.

\section{The Ether}

Parallel to these discussions and discoveries mentioned was the idea that a substance, the (luminiferous) ether, originally proposed by Newton, permeated the whole universe and was present in space and throughout matter; it was the conduit through which light and unseen waves or vibrations, as well as telepathic communications, were transmitted according to some scientists at the time (Noakes, 2019; Rousseau, 2015). Similarly, the founder of Anthropophy, Rudolf Steiner (1971), had proposed an "etheric" level of reality. Ether was seen by some not only as an all-pervading substance but also as representing the hidden interconnected nature of the universe (Henderson, 2014).

One of the foremost historians of the links between science, Occultism, and art at the turn of last century, Linda Dalrymple Henderson (e.g., 2002, 2014), considers the ideas of ether and of the fourth dimension intellectual foundations for various artistic movements of the time, including Abstract Art, Cubism, and Futurism. She mentions distinguished scientists who supported the notion of ether, including Nobel prizewinner physicist J. J. Thomson, William Crookes, Oliver Lodge, and Balfour Stewart, all of them seriously interested in psi research, and with some having presided over the Society for Psychical Research (https://www.spr.ac.uk/about/past-presidents). Lodge, among others, specifically connected the notion of the ether to psychic functioning (see Noakes, 2019).

Ether was inspirational to modern artists from different movements. For instance, Composition VI by the Abstract artist Kandinsky was designed not only to portray unseen energies, but also to directly affect the consciousness of the spectator via transmission through the ether (Henderson, 2014, p. 236). More recently, the ether has been the raison d'être for exhibits in the Centre Pompidou in 2011 (https:// www.estherschipper.com/exhibitions/203-ther.-from-cosmology-to-consciousness-christoph-keller/) and the center of contemporary art La Panacée in 2014 (https://www.montpellier.fr/4173-2014-a-lapanacee.htm).

The theory of a substance such as ether or of ethereal layers is no longer held by contemporary physicists because it was not supported by the Michelson-Morley experiments on the speed of the 
transmission of light or Einstein's theory of relativity (see Navarro, 2018). Nonetheless, proposals of a hidden underlying interconnectedness of everything in the universe are current as potential implications of quantum mechanics (QM). The important QM theoretician David Bohm wrote that the world of experienceable time and space occurs in the explicate order of the universe, but underlying it there is an implicate order or guiding field that is non-local and non-temporal, and which might explain psi phenomena (Bohm, 1986). Another distinguished theoretical physicist, Bernard d'Espagnat $(1979,2006)$, concluded that, consistent with the ideas of transcendentalists thinkers, there is a "veiled reality" that pervades the universe and interacts with consciousness (for more examples of physicists supporting the possibility of psi phenomena and a brief discussion of these ideas in the context of consciousness and psi research see Cardeña, 2018). And, as a piece of the Standar Model of physics, the Higgs energy field (not a substance) has been proposed to exist throughout the universe and endow particles with mass (https://profmattstrassler.com/articles-and-posts/particle-physics-basics/how-the-higgs-fieldworks-with-math/). More generally, while discussing the implications of Quantum Mechanics, the Nobel laureate Max Delbrück (1986) concluded that: "Modern science ... has forced us to abandon absolute space and time, determinism, and the absolute object" (p. 279). Thus, the proposal of an interconnected universe remains in contention, even though the notion of an ethereal substance has been abandoned.

\section{The Fourth Dimension}

Henderson describes another imperceptible "meta-reality" (2014, p. 235), a fourth dimension of space, underlying our ordinary three spatial dimensions. In it, events that might seem mysterious for our senses are fully manifested. This idea is consistent with an invisible order of the universe and for some, such as Steiner (1971), whose writings influenced various artists, it could explain the apparent violations of time and space in psi phenomena. Those able to sense that dimension would make sense of phenomena opaque to our ordinary senses. The astronomer and psychical researcher Zöllern also proposed that a fourth dimension could explain genuine psi manifestations during séances (Valente, 2008).

The notion of the fourth dimension was held by scientists and esoteric authors and inspired the work of various artists. For instance, the Suprematist painter Malevich used some of his paintings to represent multiple, overlapping planes, as well as a sense of infinity or vastness (or the corresponding Void) presumed to reside in such dimension (Henderson, 2015; Levy, 2011). Hilma af Klint experimented with unfolding geometric representations, for instance in a painting of a multi-dimensional crucifixion (Henderson, 2019). The geometric fourth dimension was also an inspiration to other artistic movements including Futurism and Cubism (Bauduin, 2012; Henderson, 2014), and the work of the Surrealists Matta and Onslow-Ford (Henderson, 1986).

Etheric vibration and hypergeometry were integrated by scientists and artists alike. An example of the former is the assertion by the physicists Stewart \& Tait (1876, in Henderson, 2002, pp. 130-131) that the changes in the visible universe were transferred through the ether and stored in the Unseen fourth dimension. The pioneer of abstract paiting František Kupka integrated his readings in science and theosophy (and perhaps his own mediumistic early experiences) to champion an art that would reveal the underlying reality behind the physical world (Hatch, 2013). And in his The Yellow Sound performance piece (circa 1914), Kandinsky proposed that rhythm, color, and movement would communicate a vibra- 
tion through "Hertzian waves translated into telepathy or emanations... [into] a hyperspace in which the dissipated material energy could be ... elevated to the level of spiritual energy (Vanden Heuvel, 2013, p. 206).

More recently, geometric hyperdimensionality has been discussed not only with respect to string theory (which describes that the properties of strings depend on vibrations, by the way) but to explain psi phenomena. The most developed model is by Professor of Mathematics and Astronomy Bernard Carr (2015), who posits that additional dimensions can explain why events that are temporally or spatially distant in our ordinary experience (i. e., psi phenomena) may be contiguous in additional dimensions and influence each other.

\section{Art and Psi Phenomena}

\section{Examples of Ostensible Psi Phenomena Reported by Artists}

A previous paper (Cardeña et al., 2012) gave some examples of what seem to be uncanny anticipations of unpredictable events among artists. They include the surrealist painter Victor Brauner's self-portrait showing him with an ennucleated eye, anticipating by many years a weird accident in which he would lose that eye. De Chirico's portrait of Apollinaire, with a drawn line on the head, where he would be shot later, has also been considered premonitory, (https://www.theguardian.com/culture/2003/ oct/25/art). We also discussed a play by the writer-artist-musician García Lorca that seemed to anticipate his own execution to the date of dating his piece (similar to the report by a medical student writing a note anticipating the death of his future wife, Duplessis, 2002). And the entheogenic artist Alex Grey concluded that his 1989 painting Gaia had been influenced by the later 9/11 attack (Grey, 2007).

Hilma af Klint was described by her nephew Erik as having "second sight" since she was a child when she had a vision of two coffins with the years in which she in the future came close to dying, besides other examples of ostensible synchronicity and precognition (Fant, 1989, pp. 16, 199). A strong influence on Klint was Steiner, who claimed that he could sense at a distance when an aunt committed suicide and continued to have contact with her afterwards (http://www.rudolf-steiner-handbuch.de/ images/Handbook.pdf, p. 17).

Kupka worked in his youth as a medium. And the Futurist painter and sculptor Boccioni claimed that artists could develop psychic abilities: "Who can still believe in the opacity of bodies, since our sharpened and multiplied sensitiveness has already penetrated the obscure manifestations of mediumistic phenomena? Why should we forget in our creations the doubled power of our sight, capable of giving results analogous to the X-rays?" (1973, p. 28, in Henderson, 2002).

\section{Individual Psi Art}

As mentioned earlier, Kandinsky thought that he could directly affect the consciousness of the spectator through his work, but other artists have gone further and asserted that their artistic vision can be transmitted psychically. These ideas go back to the concretization of thought and its transmission through electromagnetic waves (Daniels, 2002; Henderson, 2002; Rousseau, 2015). Kupka declared that "The artist could then make visible for the beholder the film of his rich, subjective inner world, making 
unnecessary the current labor of producing a painting or a sculpture" (in Daniels, 2002, p. 117, translation by Ana Iribas). The performance artist Marina Abramović stated that in the future the artist will be able to transmit an image directly (in Phipps, 1981, p. 50). And in Ideal Work (1969-1970), Susan Hiller wrote that "The most interesting and possibly the most adventurous form of art is direct mind-to-mind transmission of images and ideas... (Hiller, 1988, p. 76).

In Conceptual Art, the desire for an objectless art was matched to psi-mediated art. In his reflections, the pioneer of systems art Jack Burnham (1970) stated that by not including sensory information, telepathy was the ideal conceptual art. In his Psychic Series, Robert Barry created various pieces along these lines. In his Project Class (1969), he tasked art students to agree on an idea that would remain a secret and would cease to have value once it was discovered or revealed by someone. And in his famous Telepathic Piece, also of 1969, he sought "to communicate telepathically a work of art, the nature of which is a series of thoughts that are not applicable to language or image"; at the end of the exhibition the work of art was revealed in the catalogue (Lippard, 1973, p. 98). Fluxus artist Robert Filliou took a more whimsical approach to psi in his Extrasensory Misperception and Telepathic Music set of works, one of which is owned by the Centre Pompidou (Rousseau, 2015, who has other examples of purported telepathic art).

Mention should also be made of Karen Russo's 2010 work Meditations on a Triangle, in which she asked a remote viewer/clairvoyant to describe Kandinsky's 1927 Variegations in the Triangle, and then had three artists create works based on the viewer's description (the video of the remote viewing and descriptions of the artists' work are at https://vimeo.com/27655932). At times, art exhibits have taken the role of psi laboratories. In the curator and artist Christoph Keller's exhibit, Grey Magic (2015), participants were asked to take part in a telepathy experiment (https://www.estherschipper.com/exhibitions/74-grey-magic-christoph-keller/), and La Cosa Mentale exhibit included a room at the end of the exhibit dedicated to testing telepathy (Rousseau, 2015).

\section{Collective Psi Art}

A whole artistic movement, Surrealism, took psi phenomena very seriously, sought to elicit them in various ways, and even planned to carry out systematic research on the further reaches of the mind (Bauduin, 2020; Duplessis, 2002; Evrard \& Méheust, 2012). André Breton, the erstwhile Dadaist, became the figurehead of the Surrealist movement. Much has been made of the influence of Freud's notion of the unconscious and dreams on the surrealists, which Breton underlined in Le Manifeste du Surréalisme (1924), but in that same document Breton also wrote that the mind conceals strange forces. After mentioning the Freudian unconscious he remarked later that he was also very aware of the even more exciting world of the subliminal self addumbrated by F. W. H. Myers and William James (Breton, 1933). For Breton, the unconscious mind was not only the depository of instinctual urges and personal histories à-la Freud, but it also gave access to creativity and psi phenomena such as telepathy and precognition, as Myers (1903) maintained (for a contemporary discussion of the relevance of Myers's work to contemporary research in various areas of psychology and psi see Kelly et al., 2007). Thus for Breton and some in his group, the goal of Surrealism went beyond the typical interpretation of being a program to achieve the "synthesis of the human dream and material reality" (Balakian, 1986, p. 138). Breton's fascination with psi phenomena is evident in his book Nadja (Breton, 1928/1964), in which he recounts 
his encounters with the eponymous character (the former Charcot patient Léona Delcourt), whose ostensible telepathic and precognitive gifts had a greater appeal to Breton than Nadja as a person. Breton and his group took part in a reading by a psychic at the French psychical research association (Institut Métapsychique International or (MI) that could be interpreted as relating to Nadja and he and his entourage became so unruly that the police had to be summoned (Evrard, 2017). Breton kept himself abreast of the research on metapsychics (the French term for what is known in English as psychical research/ parapsychology), while metapsychics researchers were very aware of surrealist activities. Some examples of these various interconnections include the IMI dedicating a special number of their journal Revue Métapsychique to discussing Art and the Occult with a paper by Bruno on Breton (1954). Breton, in turn, published a paper (1955) referring to Bruno's article in a parapsychology journal (Duplessis, 2002).

The program of the surrealists included ways to alter consciousness and have access to this reservoir of latent psi capacities (see the second paper in this series). They first experimented with a type of sleep/mediumistic sessions (described by Breton, 1922 in Entrée des Médiums). This was followed by a more sustained practice in automatic writing and drawing, focus on dreams, and various surrealist "games," which might give an inkling of telepathic type bonds and a hidden order to reality. To describe briefly the most famous one, the chain activity "exquisite corpse," so titled after the outcome of one game, was carried out by having one person write a word (for instance a noun), and have another continue (for instance by adding an adjective) without him/her being able to see the initial text; a similar procedure entailed creating a communal drawing using folded paper in which only a very small section of the previous drawing could be seen and had to be continued by somebody else (Brotchie, 1991). Some of the drawings and texts seemed to indicate striking continuities but it is fair to point out that it is likely that unsuccessful attempts were not generally paid attention to. This directed use of "chance" could be interpreted as a type of group mind (Duplessis, 2002), or might be thought of as a synchronicity ("a meaningful coincidence of two or more events"; Jung 1951/1957, p. 201). An example of their co-creation is the book Les Champs Magnétiques by Breton and Soupault (1920).

Breton kept himself abreast of the research on metapsychics (the French term for what is known in English as psychical research/parapsychology), while metapsychics researchers were very aware of surrealist activities. Some examples of these various interconnections include the IMI dedicating a special number of their journal Revue Métapsychique to discussing Art and the Occult with a paper by Bruno (1954). Breton, in turn, published a paper (1955) referring to Bruno's article in a parapsychology journal (Duplessis, 2002).

The surrealists engaged in various activities, some potentially psi-related, within a communal context in which connections across people could be established. The idea of transient communities of shared psi mentality has been described within the therapeutic setting (e.g., Cardeña, 2019b; De Peyer, 2016), whose emotional context would be closer to that of a community of artists (or of other intense emotional connections) than the emotionally cold setting of most controlled experiments. The creation of a "psychic community" was a goal in Susan Hiller's Draw Together (1972) and The Dream Seminar (1973) created communal waking and putative dreaming psi events (see Iribas, 2020, for a thorough discussion of these and other relevant works of Hiller). Another important connection between art and psi is the work of performance artist Marina Abramović. In an interview she declared that one can learn to master telepathy in four years (in Rousseau, 2015, p. 269), and declared a direct communication with 
her late artistic and romantic partner Ulay. The also decades-long artistic collaborators Gilbert \& George declared in a 1997 interview that their joint work was "partly telepathic" (in Rousseau, 2015, p. 245).

The notion that individuals are always open to the influence of others is consistent with the anthropological concept of porous "dividuals" who are affected and defined partly by their interactions with others, rather than being isolated, impermeable beings (e.g., Cardeña \& Schaffler, 2018; Smith, 2012). This general concept is also consistent with psi research, suggesting that whether they are aware of it or not, people may be affected by others' intentions, gazes, and so on (Cardeña, 2018). This proposed openness or interdependence may go beyond specific human beings, as seen in the research on psi with non-human animals (Sheldrake, 2015), with whole communities in the Global Consciousness Project (Nelson, 2015), and with the effect of changes in solar activity on performance in psi experiments (Ryan, 2015). Fabrice Hyber has given expression to these interactions in a painting of a brain surrounded by a vast, open field (in Rousseau, 2015, p. 279).

\section{Psi Phenomena and Research as a Cultural Artifact}

A different approach has been to use or create psi phenomena, images, and films, found or created as the topic of art. The exhibit on purported spirits, auras, and séance photography The Perfect Medium (Chéroux et al., 2004) discussed it as a mostly historical, cultural artifact. Most if not all spirit photographies were created through double exposures and other trick photography techniques. Nonetheless, the catalogue included contributions on Ted Serios's "thoughtography" (Braude, 2004) and the Kluski hand casts (Schmidt, 2004), which have been more resistant to conventional explanations.

In two of her works, Wild Talents (1979) and Psi Girls (1999), Susan Hiller edited fragments of mostly commercial films showing young people manifesting psi phenomena (Iribas, 2020). The multi-award winner Susan McWilliams has based much of her art on photos and other paraphernalia related to psychical research (e.g., séances) and parapsychology (e.g., remote viewing) (https://www.susanmacwilliam. com/work). And Zoe Beloff, whose work has been exhibited at the Museum of Modern Art and the Whitney Museum, created the installation The Ideoplastic Materializations of Eva C. (2004), based on historical mediumistic séances (http://www.zoebeloff.com/pages/installations.html), and directed films on a medium and on Edison's attempt to create a machine to talk to the deceased (http://www.zoebeloff.com/pages/film.html).

The broader concept of the paranormal (which includes psi phenomena but also much more), technology, and art was explored in an exhibit in 2005 (https://cadvc.umbc.edu/blur-of-the-otherworldly-contemporary-art-technology-and-the-paranormal/), which brought attention to the ethereality and dividuality of technological life. The webpage for the exhibit, though, regrettably shows a common bias, mentioning that it is about "culturally inbred questions/superstitions." In the online material to students, the only contributor who expressed knowledge of psi research was the eminent writer and mythologist Marina Warner (https://cadvc.umbc.edu/files/2014/10/CADVC_Blur_Curriculum.pdf).

And in between art, spiritualism, and ethnography is the haunting work of the celebrated photographer Shannon Taggart (Taggart, 2019), with techniques such as long exposure times to illustrate the mysteries and uncertainties she found while immersing herself in Spiritualist communities. Inciden- 
tally, her interest was triggered by the mediumistic reading of a cousin who got very precise information about the death of a grandfather, which even the cousin did not know at the time.

\section{Conclusion}

Psi theory, research, and imagery have had considerable impact on the development of non-representational art, independently of occult themes. Theories of ether, hypergeometry, interconnectedness, the nature of the (in)dividual author, imagery from actual psi research, and speculations about the full extent of human abilities have all nurtured artistic creation. One of the common complaints about psi research is that even if the phenomena are valid, they offer little of practical use given their typical small effects and apparent lack of reliability and controllability in controlled experiments (Rousseau, 2015, p. 278, even concludes, incorrectly, that psi cannot be verified; see Cardeña, 2018). There are different responses to this objection. One is that spontanous manifestations in everyday life, as in some of the accounts of artists, can be far more precise and life-transforming than what is typically obtained in the sterile and unimportant context of an experimental setting. Another is that even the small and erratic effects obtained in experimental protocols may be used to obtain financial gain (e.g., Carson et al, 2014). Psi research has advanced scientific methodological and statististical developments such as randomization and meta-analysis, which have later percolated into science at large (Hövelmann, 2015), and there was the fruitful exchange between physics theory and research, and the puzzles of psi phenomena during the late 19th and early 20th centuries, which may occur again (Noakes, 2019). In addition, this paper shows that whether as concept, practice, experience, research, or aspiration, psi phenomena and research have inspired artistic creation and innovation for more than a century, and continue to do so.

\section{References}

Althaus, K., Mühling, M., \& Schneider, S. (2018). World receivers: Georgiana Houghton, Hilma af Klint, Emma Kuntz. And John Whitney, James Whitney, Harry Smith. Hirmer.

Anderson, Z. (2011). Colour, shape, and music: The presence of Thought Forms in abstract art. Literature \& Aesthetics, 21, 236-258.

Balakian, A. (1986). Surrealism: The road to the absolute. University of Chicago Press.

Baptista, J., Derakhshani, M., \& Tressoldi, P. E. (2015). Explicit anomalous cognition: A review of the best evidence in ganzfeld, forced choice, remote viewing and dream studies. In E. Cardeña, J. Palmer, \& D. Marcusson-Clavertz (Eds.), Parapsychology: A handbook for the 21st century (pp. 192-214). McFarland.

Bauduin, T. M. (2012). Science, occultism, and the art of the avant-garde in the early twentieth century. Journal of Religion in Europe, 5, 23-55.

Bauduin, T. M. (2020). Surrealism, Occultism and politics: In search of the marvellous. Routledge.

Berger, H. (1940). Psyche. Gustav Fischer.

Besant, A., \& Leadbeater, C. W. (1901). Thought-forms. Theosophical Publishing Society. Retrieved from https://www.gutenberg.org/files/16269/16269-8.txt

Boccioni, U. et al. (1973). Technical manifesto of futurist painting. In U. Apollonio (Ed.), Futurist manifestoes. Viking Press.

Bohm, D. (1986). A new theory of mind and matter. Journal of the American Society for Psychical Research, 80, 113-135.

Brain, R. M. (2010). How Edvard Munch and August Strindberg contracted protoplasmania: Memory, synesthesia, and the vibratory organism in Fin-de-Siécle Europe. Interdisciplinary Science Reviews, 35, 7-38. 
Brain, R. M. (2013). Materialising the medium: Ectoplasm and the quest for supra-normal biography in finde-siécle science and art. In A. Enns \& W. Trower, S. (Eds.) (2013). Vibratory modernism (pp. 115-144). Palgrave Macmillan.

Braude, S. (2004). The thoughtography of Ted Serios. Schmit, S. (2004). In C. Chéroux, A. Fischer, P. Apraxine, D. Canguilhem, \& S. Schmit (2004). The perfect medium: Photography and the occult (pp. 155-168). Yale University Press.

Breton, A. (1922). Entrèe des médiums (The entrance of the mediums). Littérature, 6, 1-6.

Breton, A. (1924). Le manifeste du surréalisme [(First) Surrealist Manifesto]. https://tcf.ua.edu/Classes/Jbutler/T340/F98/SurrealistManifesto.htm

Breton, A. (1933). Le message automatique [The automatic message]. Minotaure, 3-4. 54-65.

Breton, A. (1955). Magie quotidienne [The everyday magic]. La Tour Saint-Jacques, 1, 19-31.

Breton, A. (1964). Nadja. Gallimard. (Original work published 1928)

Breton, A., \& Soupault, P. (1920). Les champs magnétiques [The magnetic fields]. Gallimard.

Brotchie, A. (1991). A book of surrealist games. Shambhala.

Bruno, J. (1954). André Breton et la magie quotidienne [André Breton and the everyday magic]. Revue Métapsychique, 97-121.

Burnham, J. (1970). Alice's head: Reflections on Conceptual Art. Artforum, 8(6), 37-43

Camfield, W. A. (2013). Max Ernst. DADA and the dawn of surrealism. Prestel.

Cardeña, E. (2012). Review of The message: Kunst und Okkultismus. Art and Occultism edited by Dichter, C., Golinski, H. G., Krajewski, M., \& Zander, S. Journal of Parapsychology, 76, 185-188.

Cardeña, E. (2014). A call for an open, informed, study of all aspects of consciousness. Frontiers in Human Neuroscience, doi: 10.3389/fnhum.2014.00017.

Cardeña, E. (2015). Eminent people interested in psi. Retrieved May 11, 2020 from https://psi-encyclopedia. spr.ac.uk/articles/eminent-people-interested-psi

Cardeña, E. (2018). The experimental evidence for parapsychological phenomena: A review. American Psychologist, 73, 663-677. doi: 10.1037/amp0000236

Cardeña, E. (2019a). Abracadabra psi? (A review of Real Magic: Ancient Wisdom, Modern Science, and a Guide to the Secret Power of the Universe, by Dean Radin). Journal of Parapsychology, 83, 93-96. http:// doi.org/10.30891/jopar.2019.01.08

Cardeña, E. (2019b). Mind leaks: A commentary on Wooffitt's: "Poetic confluence: A sociological analysis of an enigmatic moment." Psychoanalytic Dialogues. The International Journal of Relational Perspectives, 29, 346-354. doi.org/10.1080/10481885.2019.1614829

Cardeña, E., Iribas, A. E., \& Reijman, S. (2012). Art and psi. Journal of Parapsychology, 76, 3-25.

Cardeña, E., Lynn, S. J., \& Krippner, S. (2017). The psychology of anomalous experience: A rediscovery. Psychology of Consciousness: Theory, Research, and Practice, 4, 4-22.

Cardeña, E., Palmer, J., \& Marcusson-Clavertz, D. (Eds.) (2015). Parapsychology: A handlbook for the 21st century. McFarland.

Cardeña, E., \& Schaffler, Y. (2018). "He who has spirits must work a lot”: A psychoanthropological account of spirit possession in the Dominican Republic. Ethos, 46, 457-476. doi.org/10.1111/etho.12216

Carr, B. (2015). Higher dimensions of space and time and their implications for psi. In E. C. May \& S. B. Marwaha (Eds.), Extrasensory perception: Support, skepticism, and science. Vol. 2: Theories of psi (pp. 21-61). Praeger.

Carson, C., Laham, D., \& Moddel, G. (2014). Stock market prediction using associative remote viewing by inexperienced remote viewers. Journal of Scientific Exploration, 28, 7-16.

Chéroux, C., Fischer, A., Apraxine, P., Canguilhem, D., \& Schmit, S. (2004). The perfect medium: Photography and the occult. Yale University Press.

Daniels, D. (2002). Kunst als Sendung: Von der Telegrafie zum Internet [Art as emission: From telegraphy to internet]. C. H. Beck. 
Delbrück, M. (1986). Mind from matter? Blackwell Scientific Publications.

De Peyer, J. (2016). Uncanny communications and the porous mind. Psychoanalytic Dialogues, 26, 156174. doi:10.1080/10481885.2016.1144978

d'Espagnat, B. (1979, November). The quantum theory and reality. Scientific American, 251, 158 -181. http://dx.doi.org/10.1038/scientificamerican1179-158.

d'Espagnat, B. (2006). On physics and philosophy. Princeton University Press.

Dichter, C., Golinski, H. G., Krajewski, M., \& Zander, S. (Eds.) (2007). The message: Kunst und Okkultismus. Art and Occultism. Walther Köenig.

Duits, C. (1974). La conscience démonique [The daimonic consciousness). Denoël.

Duplessis, Y. (2002). Surréalisme et paranormal. L'aspect expérimental du surréalisme [Surrealism and the paranormal. The experimental aspect of surrealism]. JMG éditions.

Enns, A. (2013). Vibratory photography. In A. Enns \& W. Trower, S. (Eds.) (2013). Vibratory modernism (pp. 177-197). Palgrave Macmillan.

Enns, A., \& Trower, S. (Eds.) (2013). Vibratory modernism. Palgrave Macmillan.

Evrard, R. (2017). Obituary. Yvonne Duplessis. Journal of Scientific Exploration, 31, 705-708.

Evrard, R., \& Méheust, B. (2012). La métapsychique, une science surréaliste? Éléments d'histoire [Metapsychics, a surrealist science ? Elements of a history]. In Entrée des médiums. Spiritisme et art de Hugo à Breton (pp. 93-102). Maison Victor Hugo - Paris-Musées.

Fant, Å. (1989). Hilma af Klint. Ockult målarinna och abstrakt pionjär [Hilma af Kint. Occultist painter and abstractionism pioneer]. Raster.

Ferris, A., Gunning, T., \& Thurschwell, P. (2003). The disembodied spirit. Bowdoin College Museum of Art.

Flammarion, C. (1907). Mysterious psychic forces: An account of the author's investigations in psychical research, together with those of other European savants. Kessinger.

Goff, H. (2005). Science and the seance. BBC News. http://news.bbc.co.uk/2/hi/uk_news/magazine/4185356.stm

Gorsen, P. (2007). Die Eintritt des Mediumismus in die Kunstgesichte/The entrance of mediumism into the history of art. In C. Dichter, H. G. Golinski, M. Krajewski, \& S. Zander (Eds.), The message. Kunst und Okkultism/Art and Occultism (pp. 17-32, 169-182). Walther König.

Grey, A. (2007). Chapel of sacred mirrors: COSM tour book. CoSM Press.

Hartmann, E., Harrison, R., \& Zborowski, M. (2001). Boundaries in the mind: Past research and future directions. North American Journal of Psychology, 3, 347-368.

Hatch, J. G. (2013). A sense and essence of nature: Wave patterns in the paintings of Frantisek Kupka. In A. Enns \& W. Trower, S. (Eds.) (2013). Vibratory modernism (pp. 145-161). Palgrave Macmillan.

Henderson, L. D. (1986). Mysticism, romanticism, and the fourth dimension. In M. Tuchman (Ed.), The spiritual in art: Abstract painting 1890-1985 (pp. 219-237). Abbeville Press.

Henderson, L. D. (Ed.) (1987, Spring). Mysticism and occultism in Modern Art. Art Journal.

Henderson, L. D. (2002). Vibratory Modernism: Boccioni, Kupka, and the ether of space. In T. Lenoir \& H. U. Gumbrecht (Eds.), Writing science (pp. 126-149). Stanford University Press.

Henderson, L. D. (2014). Abstraction, the ether, and the fourth dimension: Kandinsky, Mondrian, and Malevich in context. In M. Ackermann, I. Malz (Eds.), Der weiße Abgrund Unendlichkeit. The infinite white abyss (pp. 233.245). Snoeck.

Henderson, L. D. (2019). Hilma af Klint and the invisible in her occult and scientific context. In K. Almqvist \& L. Belfrage (Eds.), Hilma af Klint visionary. Stolpe.

Hiller, S. (1998). Ideal work. In Experimental art foundation: Ideal Work (pp. 75-79). EAF.

Hoffman, W. (2010). L'art fantastique [The art of fantasy]. Hirmer.

Holt, N. J. (2019). The expression of schizotypy in the daily lives of artists. Psychology of Aesthetics, Creativity, and the Arts, 13, 359-371. https://doi.org/10.1037/aca0000176

Hövelmann, G. H. (2015). On the usefulness of parapsychology for science at large. In E. Cardeña, J. Palmer, \& D. Marcusson-Clavertz (Eds.), Parapsychology: A handbook for the 21st century (pp. 389-398). McFarland. 
Houghton, G. (1882). Chronicles of the photographs of spiritual beings and phenomena invisible to the material eye. E. W. Allen.

Iribas, A. E. (2020). Psi and anomalous experiences in Susan Hiller's oeuvre. Journal of Parapsychology, 84, $179-201$.

Jung, C. G. (1957). On synchronicity. In J. Campbell (Ed.), Man and time. Papers from the Eranos Yearbook. Princeton University Press.

Kandinsky, V. (1979). De lo espiritual en el arte [Concerning the spiritual in art]. Premia. (Originally published 1911).

Kelly, E. F., Kelly, E. W., Crabtree, A., Gauld, A., Grosso, M., \& Greyson, B. (2007). Irreducible mind: Toward a psychology for the 21st century. Rowan \& Littlefield.

Kelly, E. W., \& Tucker, J. B. (2015). Research methods with spontaneous case studies. In E. Cardeña, J. Palmer, \& D. Marcusson-Clavertz (Eds.), Parapsychology: A handbook for the 21st century (pp. 63-76). McFarland.

Klee, P. (1920). Creative credo. https://arthistoryproject.com/artists/paul-klee/creative-credo/

Köhler, W. (1929). Gestalt psychology. Liveright.

Krämer, F. (Ed.) (2012). Schwarze Romantik: Von Goya bis Max Ernst [Dark Romanticisism: From Goya to Max Ernst]. Hatje Canz.

Levy, M. (2011). Altered consciousness and modern art. In E Cardeña \& M Winkelman (Eds.), Altering consciousness. A multidisciplinary perspective. Volume I. History, culture, and the humanities (pp. 327-354). Praeger.

Lingan, E. B. (2014). The theatre of the occult revival: Alternative spiritual performance from 1875 to the present. Palgrave Macmillan.

Lippard, L. (1973). Six years: The dematerialization of the art object from 1966 to 1972. Praeger.

Lundkonsthall (2013). I stömmen. Channelled. Author.

Marks, L. E. (2000). Synesthesia. In E. Cardeña, S. J. Lynn, y S. Krippner (Eds.), Varieties of anomalous experience: Examining the scientific evidence (pp. 121-150). American Psychological Association.

Méheust, B. (1999). Somnambulisme et médiumnité - Tome 2. Le choc des sciences psychiques [Somnambulism and mediumnism. Vol. 2. The shock of the psychical sciences]. Les Empêcheurs de penser en rond.

Mitchell, T. M., Shinkareva, S. V., Carlson, A., Chang, K. M., Malave, V. L., Mason, R. A., \& Just, M. A. (2008). Predicting human brain activity associated with the meanings of nouns. Science, 320, 1191-1195.

Myers, F. W. H. (1903). Human personality and its survival of bodily death. Longmans, Green.

Navarro, J. (Ed.) (2018). Ether and modernity: The recalcitrance of an epistemic object in the early twentieth century. Oxford University Press.

Nelson, R. D. (2015). Implicit physical psi: The global consciousness project. In E. Cardeña, J. Palmer, \& D. Marcusson-Clavertz (Eds.), Parapsychology: A handbook for the 21st century (pp. 282-292). McFarland. Noakes, R. (2019). Physics and psychics: The occult and the sciences in modern Britain. Cambridge University Press. Okuda, O. (2011) Le métamorphose médiumnique chez Paul Klee [The mediumistic metamorphosis of Paul Klee]. In J. Pijaudier Cabot \& S. Faucherau (Eds.), L'Europe des esprits ou la fascination de l'occulte, 1750-1950 [The Europe of the spirits or the fascination of the occult] (pp. 278-287). Éditions de Musées de Strasbourg, 278-87.

Oursler, T. (2019). Notes on mysticism and visual transects. In S. Taggart, Séance (pp. 11-27). Fulgur Press. Phipps, J. (1981). Marina Abramović /Ulay, Ulay/Marina Abramović. Art \& Text, 3, 43-50.

Pijaudier-Cabot, J., \& Fauchereau, S. (Eds.) (2011). L'Europe des esprits ou la fascination de'occulte, 17501950 [The Europe of the spirits or the fascination of the occult]. Editions des Musées de Strasbourg.

Radin, D., Michel, L., \& Delorme, A. (2016). Psychophysical modulation of fringe visibility in a distant double-slit optical system. Physics Essays, 29, 14-22. http://dx.doi.org/10.4006/0836-1398-29.1.014

Richter, H. (1965). dada: art and anti-art. Thames \& Hudson.

Ringbom, S. (1986). Transcending the visible: The generation of the abstract pioneers. In M. Tuchman (Ed.), The spiritual in art: Abstract painting 1890-1985 (pp. 131-153). Abbeville Press. 
Riskin, J. (2020). Just use your thinking pump! [Review of The Scientific Method: An Evolution of Thinking from Darwin to Dewey]. New York Review of Books, 67(11), 48-50.

Rosenthal, M. (1982). The prototypical triangle of Paul Klee. The Art Bulletin, 44, 299-310.

Rousseau, P. (2015). Cosa mentale. Art et télépathie au XXe siècle [The mental thing: Art and telepathy in the $29^{\text {th }}$ century]. Gallimard.

Ryan, A. (2015). Physical correlates of psi. In E. Cardeña, J. Palmer, \& D. Marcusson-Clavertz (Eds.), Parapsychology: A handbook for the 21st century (pp. 181-191). McFarland.

Safarova, B., Zemánkova, T., \& Hattori, T. (2012). Anatomia metamorphosis. Hyogo Prefectural Museum of Art.

Schlitz, M. J., \& Honorton, C. (1992). Ganzfeld psi performance within an artistically gifted population. Journal of the American Society for Psychical Research, 86, 83-98.

Schmit, S. (2004). Franek Kluski's casts. In C. Chéroux, A. Fischer, P. Apraxine, D. Canguilhem, \& S. Schmit (2004). The perfect medium: Photography and the occult (pp. 268-269). Yale University Press.

Sheldrake, R. (2015). Psi in everyday life: Nonhuman and human. In E. Cardeña, J. Palmer, \& D. Marcusson-Clavertz (Eds.), Parapsychology: A handbook for the 21st century (pp. 350-363). McFarland.

Sinclair, U. (1930). Mental radio (preface by Albert Einstein). Author.

Smith, K. (2012). From dividual and individual selves to porous subjects. The Australian Journal of Anthropology, 23, 50-64. doi:10.1111/taja.2012.23.issue-1

Steiner, R. (1971). Theosophy: An introduction to the supersensible knowledge of the world and the destination of man. https://wn.rsarchive.org/Books/GA009/English/AP1971/GA009_index.html

Sueur-Hermel. (2016). Fantastique! L'etampe visionnaire de Goya a Redon [Fantastic! The visionary view from Goya to Redon]. Bibliotèque National de France.

Taggart, S. (2019). Séance. Fulgur Press.

Tallman, S. (2019). Painting the beyond. The New York Review of Books, 4(66), 9-11.

Tuchman, M. (1986). The spiritual in art: Abstract painting 1890-1985. Abbeville Press.

Valente, K. G. (2008). "Who will explain the explanation?" The ambivalent reception of higher dimensional space in the British Spiritualist press. Victorian Periodicals Review, 41, 124-149.

Vanden Heuvel, M. (2013). Good vibrations: Avant-garde theatre and ethereal aesthetics from Kandinsky to Futurism. In A. Enns \& W. Trower, S. (Eds.) (2013). Vibratory modernism (pp. 198-214). Palgrave Macmillan.

Watt, C., Dawson, E., Tullo, A., Pooley, A., \& Rice, H. (2020). Testing precognition and alterations of consciousness with selected participants in the ganzfeld. Journal of Parapsychology, 84, 21-37.

Wynands, S. (2001). Zürich Dada and mysticism. Literature \& Theology, 15,70-84.

\section{Représenter l'Éthéré, Partie 1 : Les Arts Visuels et le Psi}

Résumé: Le passage de l'art figuratif à la représentation d'expériences internes a incité les artistes à mettre en avant leurs propres expériences anomales et autres phénomènes psi apparents. Diverses études ont décrit comment l'art abstrait était influencé par l'occultisme, mais il y avait d'autres influences importantes. Parmi elles, les théories scientifiques des dimensions éthérées et hypergéométriques, le développement des avancées technologiques montrant la réalité des ondes électromagnétiques invisibles et la communication sans fil à distance, le spiritisme et les débuts de la recherche psychique. Cet article se concentre sur la façon dont les phénomènes psi, ainsi que la recherche et la théorie parapsychologiques, souvent en conjonction avec ces autres influences, ont été un sujet et une source d'inspiration importants dans divers mouvements modernes et contemporains, notamment le surréalisme et l'art abstrait et conceptuel. 


\section{Das Ätherisch abbilden, Teil I: Visuelle Kunst und Psi}

Zusammenfassung: Die Wende von der gegenständlichen Kunst zur Darstellung innerer Erfahrungen öffnete den Künstlern die Tür zur Darstellung anomaler Erfahrungen und scheinbarer Psi-Phänomene. Verschiedene Studien haben beschrieben, wie die Abstrakte Kunst vom Okkultismus beeinflusst wurde, aber es gab auch andere wichtige Einflüsse. Dazu gehören wissenschaftliche Theorien über den Äther und höherdimensionale Geometrien, technologische Fortschritte, die die Realität unsichtbarer elektromagnetischer Wellen und drahtloser Kommunikation auf Entfernung zeigten, der Spiritualismus und die Anfänge der parapsychologischen Forschung. Dieser Beitrag konzentriert sich darauf, zu zeigen, wie PsiPhänomene in Forschung und Theorie, oft in Verbindung mit den anderen Einflüssen, zu einem wichtigen Thema und einer Inspirationsquelle für verschiedene moderne und zeitgenössische Bewegungen einschließlich des Surrealismus und der Abstrakten und Konzeptkunst wurden.

\section{Representando lo Etéreo, Parte I: Arte Visual y Psi}

Resumen: El giro de arte figurativo a la manifestación de experiencias internas abrió la puerta para que los artistas plasmaran experiencias anómalas y aparentes fenómenos psi. Varios estudios han descrito cómo el ocultismo influyó en el arte abstracto, pero hubieron otras influencias importantes, incluyendo: teorías científicas del éter y las dimensiones hipergeométricas, el desarrollo de avances tecnológicos que mostraron la realidad de las ondas electromagnéticas invisibles y la comunicación inalámbrica a distancia, el espiritismo, y el inicio de la investigación psíquica. Este artículo se centra en cómo los fenómenos psíquicos, junto con su investigación y teoría, a menudo junto con otras influencias, han sido un tema importante y fuente de inspiración para varios movimientos artísticos modernos y contemporáneos, incluyendo al surrealismo y al arte abstracto y conceptual. 